\title{
Numerical simulation of debris flows triggered from the Strug rock fall source area, W Slovenia
}

\author{
M. Mikoš ${ }^{1}$, R. Fazarinc ${ }^{2}$, B. Majes ${ }^{1}$, R. Rajar ${ }^{1}$, D. Žagar ${ }^{1}$, M. Krzyk ${ }^{1}$, T. Hojnik ${ }^{3}$, and M. Četina ${ }^{1}$ \\ ${ }^{1}$ Faculty of Civil and Geodetic Engineering, University of Ljubljana, Ljubljana, Slovenia \\ ${ }^{2}$ Water Engineering Ltd., Ljubljana, Slovenia \\ ${ }^{3}$ Water Management Bureau Ltd. (Vodnogospodarski Biro Maribor d.o.o.), Glavni trg 19c, 2000 Maribor, Slovenia
}

Received: 4 October 2005 - Revised: 27 January 2006 - Accepted: 15 February 2006 - Published: 24 April 2006

\begin{abstract}
The Strug landslide was triggered in December 2001 as a rockslide, followed by a rock fall. In 2002, about 20 debris flows were registered in the Koseč village; they were initiated in the Strug rock fall source area. They all flowed through the aligned Brusnik channel, which had been finished just before the first debris flow reached the village in April 2002. Debris flow events were rainfall-induced but also governed by the availability of rock fall debris in its zone of accumulation. After 2002 there was not enough material available for further debris flows to reach the village. Nevertheless, a decision was reached to use mathematical modeling to prepare a hazard map for the village for possible new debris flows. Using the hydrological data of the Brusnik watershed and the rheological characteristics of the debris material, 5 different scenarios were defined with the debris flow volumes from $1000 \mathrm{~m}^{3}$ to a maximum of $25000 \mathrm{~m}^{3}$. Two mathematical models were used, a one-dimensional model DEBRIF-1D, and a two-dimensional commercially available model FLO-2D. Due to the lack of other field data, data extracted from available professional films of debris flows in 2002 in the Koseč village were used for model calibration. The computational reach was put together from an 800-m long upstream reach and 380-m long regulated reach of the Brusnik channel through the village of Koseč. Both mathematical models have proved that the aligned Brusnik channel can convey debris flows of the volume up to $15000 \mathrm{~m}^{3}$. Under the most extreme scenario a debris flow with $25000 \mathrm{~m}^{3}$ would locally spill over the existing levees along the regulated Brusnik channel. For this reason, additional river engineering measures have been proposed, such as the raising of the levees and the construction of a right-hand side sedimentation area for debris flows at the downstream end of the regulated reach.
\end{abstract}

Correspondence to: $\mathrm{M}$. Mikoš

(mmikos@fgg.uni-lj.si)

\section{Introduction}

In the paper, unsteady numerical simulations of debris flows triggered in the Strug rock fall source area, W Slovenia, are shown. The two models used (one 1-D and one 2-D) were calibrated by data extracted from the professional films of some debris flow events in 2002 and partly by the application of the same models to the previous case of debris flow simulations below Stože in November 2000 (Četina et al., 2006). The main aim of the calibration of a mathematical model and performing numerical simulations was to prepare the hazard map for the area around Kosec village below the Strug rock fall.

Simple models have been developed using field experience or evidence from old debris flows to estimate, for example, maximal debris flow volumes (magnitudes) triggered during extreme events in an arbitrary watershed of known size (Rickenmann, 1999; Marchi and D’Agostino, 2004) or to assess maximum runout distances and areas covered by debris flows from their estimated volumes (Legros, 2002; Lorente et al., 2005). Even though one assumes where and when a debris flow will be triggered, its physical and rheological characteristics (e.g. magnitude, density, viscosity) are of paramount importance for its routing from the source to the deposition area.

Furthermore, advanced mathematical models have been developed so far to describe debris-flow dynamics. Numerous 1-D models have been proposed and applied (Jin and Fread, 1997; Brufau et al., 2000; Bertolo and Wieczorek, 2005; Četina et al., 2006), used under different conditions. Also 2-D models have found wide acceptance, among them the commercially available FLO-2D model was used extensively. So far, it has been tested and then applied for simulation purposes in a variety of conditions such as for catastrophic debris flows on alluvial fans in Vargas, Venezuela (Garcia et al., 2003), small viscous debris flows in alpine

Published by Copernicus GmbH on behalf of the European Geosciences Union. 


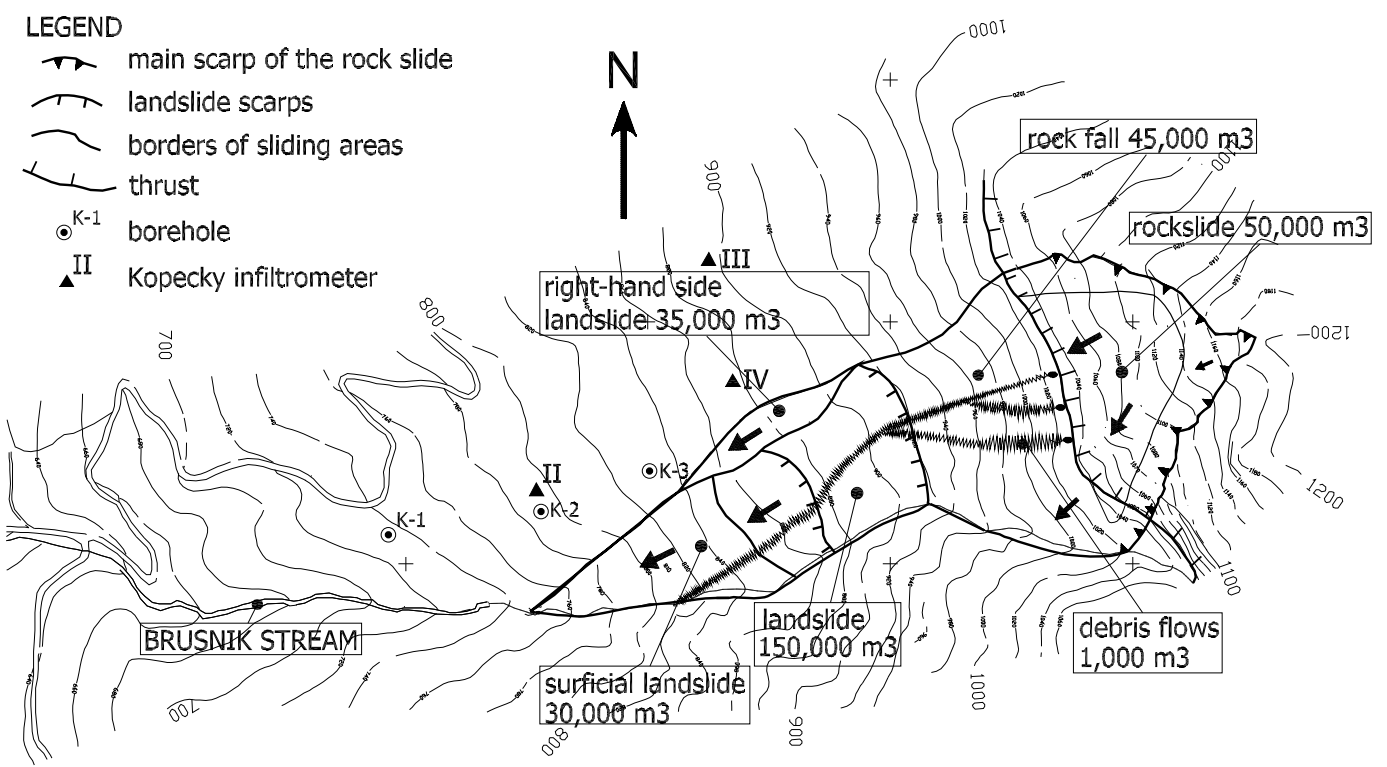

Fig. 1. Plan view of different slope instability processes in the Strug landslide area.

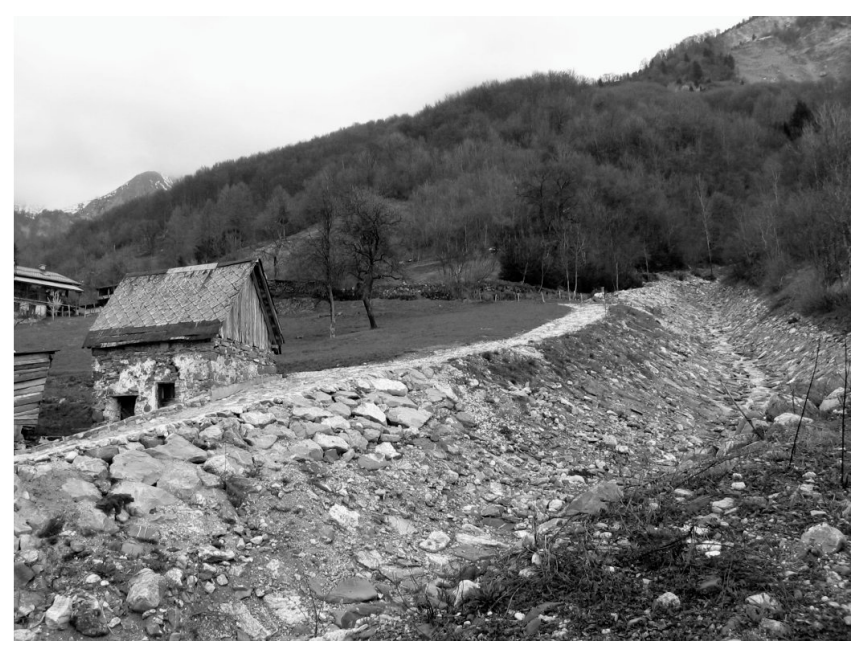

Fig. 2. The aligned Brusnik channel in the village of Koseč in the upstream reach of the bridge (cross section \# 13). The Strug rock fall source area can be seen in the upper right-hand corner of the photo.

torrential catchments in Austria (Hübl and Steinwendtner, 2001), small debris flows in Yosemite Valley in California, USA (Bertolo and Wieczorek, 2005), post-fire debris flows in Colorado, USA (Elliot et al., 2005), volcano lahars in Ecuador (Canuti et al., 2002), debris flows in Taiwan triggered by typhoons and earthquakes (Lin et al., 2005), numerous rainfall events triggered debris slides in volcanoclastic deposits in Southern Italy (Aleotti and Polloni, 2003), or for the large Stože debris flow in the Julian Alps in Slovenia (ČCetina et al., 2006). The majority of users of mathematical modeling claimed the usefulness of such an approach when preparing hazard maps in debris-flow prone areas.

1.1 The dynamics of the Strug landslide and simulation scenarios

In December 2001, the Strug rockslide, with an estimated $95000 \mathrm{~m}^{3}$, was triggered on the southwest slopes of the Planica Mountain (1376 m a.s.1.) in the Krn Mountains above the Koseč village $(650 \mathrm{~m}$ a.s.1.) in the Julian Alps, W Slovenia. It was initiated at the contact between a high permeable calcareous rocks (Cretaceous scaglia) thrust over nearly impermeable clastic rocks' (Cretaceous flysch). A few days later, a rock fall, with an estimated volume of $45000 \mathrm{~m}^{3}$, was initiated within the rockslide (Fig. 1). The kinetic push of the rock fall caused the immediate displacement of a translational landslide, with a volume of $180000 \mathrm{~m}^{3}$, that partially slipped into the torrential ravine of the Brusnik Stream. After the rockslide suddenly dropped for $15 \mathrm{~m}$ in December 2001, its velocity exponentially slowed down to less than $10 \mathrm{~m} / \mathrm{year}$ until the end of 2002, and came to a practical stillstand in 2003. More details on this complex landslide are given elsewhere (Mikoš et al., 2006).

Soon after the rockfall in December 2001, a question arose as to whether the debris flows could be initiated in rock fall masses during prolonged rainfalls, possibly as soon as in the first wet period of 2002. Therefore, the channel of the Brusnik Stream was enlarged. A parabolic cross section was chosen to enable good conveyance for possible debris flows (Fig. 2), and a small arch bridge in the village was replaced by a larger one.

After the rainfall in spring 2002, small debris flows made of clayey gravels, up to several $100 \mathrm{~m}^{3}$, started to flow from 
the zone of accumulation of the rock fall over the landslide along the channel of the Brusnik Stream. The construction works in the Brusnik channel were completed just before the first debris flow reached the village of Koseč on 22 April 2002. More than 20 debris flow events, with volumes between some $100 \mathrm{~m}^{3}$ and $1000 \mathrm{~m}^{3}$, were registered to reach the Kosec village in 2002 (Fig. 3) and passed through the new regulated Brusnik Stream channel towards the Ročica Torrent and the Ladra village. The enlarged and regulated Brusnik channel successfully withstood all debris flows without any overflow.

The statistical analysis showed that debris flows were initiated at daily rainfall between 20 to $30 \mathrm{~mm}$, depending on the antecedent precipitation. This value may be taken as a specific hydrologic threshold for this site. Because in 2003 and 2004 no more debris flows were registered, the conclusion was drawn that debris flow events were rainfall-induced but also governed by the availability of rock fall debris in its zone of accumulation (Mikoš et al., 2005).

The Brusnik Stream basin area is $0.80 \mathrm{~km}^{2}$, and it flows through Koseč and into the Ročica Torrent (basin area of $10.8 \mathrm{~km}^{2}$ ). In order to help with model calibration, samples from 3 boreholes (see Fig. 1 for locations) and samples from the Brusnik channel downstream from the landslide were used for laboratory investigation on their rheological characteristics. For fines $(<0.08 \mathrm{~mm})$ from channel samples, the liquid limit was 50\%, the plastic limit was $19 \%$ and the plasticity index PI was $31 \%$. The fines were classified to be on the limit between low and high plasticity clays. Other geotechnical properties of the channel samples are given in Table 1.

The first step to model future debris flows was to establish scenarios regarding the volume of debris flows and their timing. The main aim of the modeling was to propose technical measures for mitigation or to decide about permanent evacuation of the endangered houses near the Brusnik Stream. For this purpose an official hazard and risk map had to be prepared as part of the procedure to enforce an official location map for the Strug hazard area.

Three scenarios with different magnitudes at $1000 \mathrm{~m}^{3}$, $5000 \mathrm{~m}^{3}$ and $15000 \mathrm{~m}^{3}$ were assumed. Additionally, an extreme event was assumed during a 10-year return period rainfall, with a duration of $3 \mathrm{~h}$, giving the total water runoff of $11000 \mathrm{~m}^{3}$ if using a hydrologic model of the watershed. Taking into account the maximal volume coefficient of $\mathrm{C}_{v}=0.55$, with the ratio between the sediment volume and the volume of a sediment-water mixture for debris flows still behaving like a fluid (FLO Eng., 1999), the extreme scenario was estimated at $25000 \mathrm{~m}^{3}$. This assumption is in line with field observations that extreme debris flows are associated with relatively frequent flood events of the order of 10-year to 25-year storms (O'Brien, 2003), because there is insufficient sediment available in the Strug rock fall source area for larger floods.

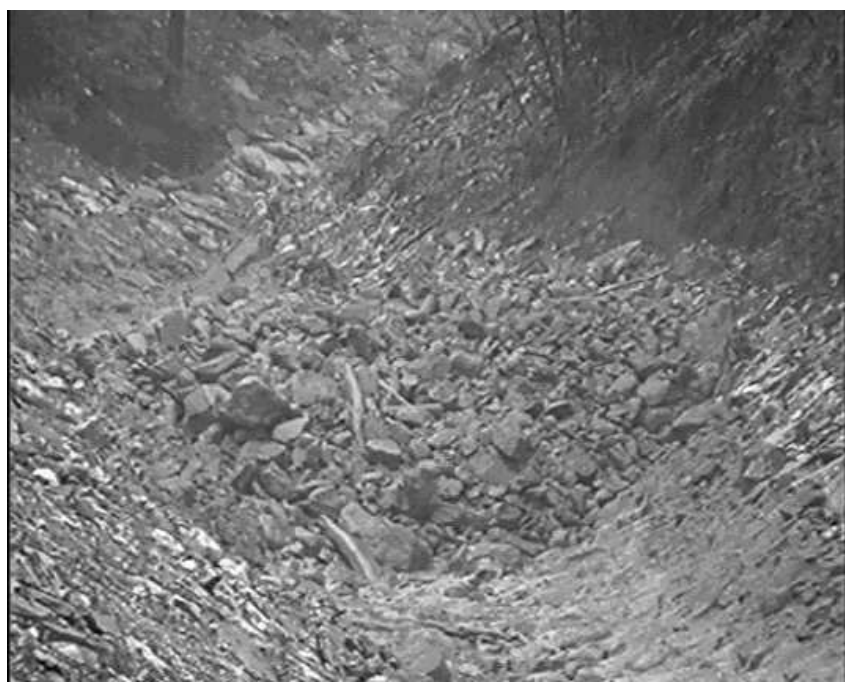

Fig. 3. Image taken from a film of the second surge of a debris flow event (7 June 2002, 11:00 a.m.) in Koseč village. The debris flow front was about $3 \mathrm{~m}$ thick.

When modeling the Stože debris flow (Četina et al., 2006), a wet debris flow was more hazardous than the dry one, due to its higher flow velocities. Therefore, a fifth scenario with $20000 \mathrm{~m}^{3}$ of wet mixture was added, assuming the volume coefficient of $\mathrm{C}_{v}=0.45$. Using the measured sediment density of $27.14 \mathrm{kN} / \mathrm{m}^{3}$, determined from sediment samples in a laboratory, the bulk mixture densities for the dry debris flow were calculated at $19.4 \mathrm{kN} / \mathrm{m}^{3}$ (using estimated $\mathrm{C}_{v}=0.55$ ) and for the wet debris flow at $17.7 \mathrm{kN} / \mathrm{m}^{3}$ (using estimated $\mathrm{C}_{v}=0.45$ ).

In the case of the Stože debris flow simulations (described in detail in Četina et al., 2006) three numerical models were used: a DEBRIF-1D model, and two 2-D models: FLO-2D and PCFLOW-2D. The first section, where the Stože debris flow was in a narrow and very steep canyon, was $4200 \mathrm{~m}$ long and the DEBRIF-1D model was used. It was possible to make a relatively good model calibration, as good measurements of debris flow traces along the channel were carried out after the event. From both 2-D models used, the widely used FLO-2D model was chosen to be used for numerical simulations of debris flows triggered from the Strug rock fall source area.

\section{Development of the mathemical models for debris flows}

\subsection{One-dimensional model}

A 1-D model for the simulation of dam break flow was developed in 1972 (Rajar, 1978), adapted for the simulation of snow avalanches (Rajar, 1980). In 2000 this model was extended to the debris flow model DEBRIF-1D. 
Table 1. Main geotechnical parameters of the samples from the Strug landslide (Majes et al., 2002).

\begin{tabular}{lllll}
\hline $\begin{array}{l}\text { water content } \\
\mathrm{w}\end{array}$ & $\begin{array}{l}\text { Weight sediment con- } \\
\text { centration } \\
(-)\end{array}$ & $\begin{array}{l}\text { Suspension bulk } \\
\text { density }\end{array}$ & $\begin{array}{l}\text { Volumetric sediment concen- } \\
\text { tration } \\
(-)\end{array}$ & $\begin{array}{l}\text { Undrained } \\
\mathrm{C}_{v} \\
\text { shear }\end{array}$ \\
& & $(-)$ & $\begin{array}{l}\left.\mathrm{m}^{3}\right) \\
\text { strength } \\
(\mathrm{kPa})\end{array}$ \\
\hline 0.30 & 0.77 & 1940 & 0.55 & 18.58 \\
0.35 & 0.74 & 1834 & 0.50 & 7.33 \\
0.40 & 0.71 & 1720 & 0.45 & 4.79 \\
0.50 & 0.67 & 1700 & 0.42 & 1.15 \\
0.60 & 0.63 & 1640 & 0.38 & 0.51 \\
\hline
\end{tabular}

$\gamma_{s}=2714 \mathrm{~kg} / \mathrm{m}^{3}$ for sediment density; $\mathrm{C}_{w}=1 /(1+\mathrm{w}) ; \mathrm{C}_{v}=\left(\gamma / \gamma_{s}\right) \mathrm{C}_{w}$

The main difference in the three phenomena lies in the formulation of flow resistance, and in the information of initial and boundary conditions. The DEBRIF-1D model solves the well-known continuity and momentum equation in the socalled "conservation" form, valid for shallow water depthaveraged flow (Rajar, 1978). The friction slope $S_{f}$, i.e. slope of energy losses along the channel, is calculated by the rheologic model of O'Brien et al. (1993):

$S_{f}=\tau_{y} /\left(\gamma_{m} \times h\right)+(K \times V \times \eta) /\left(8 \gamma_{m} \times h^{2}\right)+\left(n_{g} \times V\right)^{2} /\left(h^{4 / 3}\right)$,

where the three terms on the right hand side of the equation are due to yield shear stress, laminar resistance, and quadratic resistance, respectively. In Eq. (1) $h$ is the flow depth, $V$ is the flow velocity perpendicular to the cross section $(\mathrm{m} / \mathrm{s}), \eta$ is viscosity (Pa.s), $\tau_{y}$ is the yield stress of the debris flow mixture $\left(\mathrm{Pa}=\mathrm{N} / \mathrm{m}^{2}\right), K$ is the coefficient of laminar resistance, $\gamma_{m}$ is the bulk density of the mixture, and $n_{g}$ the (equivalent) Manning roughness coefficient $\left(\mathrm{s} . \mathrm{m}^{-1 / 3}\right)$. The system of two equations is solved by the Lax-Wendroff numerical method. The topography of the channel is given with a numerical description of the cross sections (channel width at given depths). In this case the distance between the cross sections was $1.0 \mathrm{~m}$ for the calibration cases and $2.5 \mathrm{~m}$ for the final simulations.

The DEBRIF-1D model includes the computation of the initial flow hydrograph $\mathrm{Q}(\mathrm{t})$ at the downstream end of the initial debris mass ("dam site"). The procedure is the same as in the dam-break flow model (Rajar, 1978; Četina et al., 2006), where at the first instant after the dam collapse the water level and velocity at the dam site are calculated by the momentum and continuity equations and the equation of the forward characteristic.

\subsection{Two-dimensional model}

For two-dimensional modeling the commercially available FLO-2D model was applied (VGB, 2004). This model was already successfully used to model the Stože debris (Četina et al., 2006). In this model, a debris flow is taken as a
non-Newtonian fluid and described with the Julien-O'Brien rheologic model, adapted to the two-dimensional situation (O'Brien et al., 1993). The friction slopes $\mathrm{S}_{f x}$ and $\mathrm{S}_{f y}$ in the $\mathrm{x}$ and $\mathrm{y}$ directions are defined as follows:

$$
\begin{aligned}
S_{f x}= & \tau_{y} /\left(\gamma_{m} \times h\right)+(K \times u \times \eta) /\left(8 \gamma_{m} \times h^{2}\right) \\
& +\left(n_{g}^{2} \times u \times\left(u^{2}+v^{2}\right)^{1 / 2}\right) / h^{4 / 3} \\
S_{f y}= & \tau_{y} /\left(\gamma_{m} \times h\right)+(K \times v \times \eta) /\left(8 \gamma_{m} \times h^{2}\right) \\
& \left.+\left(n_{g}^{2} \times v \times\left(u^{2}+v^{2}\right)^{1 / 2}\right) / h^{4 / 3}\right),
\end{aligned}
$$

where $u$ and $v$ are flow velocities in the $\mathrm{x}$ and $\mathrm{y}$ directions $(\mathrm{m} / \mathrm{s})$. A more detailed description of the model can be found elsewhere (FLO Eng, 1999).

\subsection{Calibration of the models}

For calibration of the models, available professional films of debris flow surges shot by a local TV station in 2002 in the Koseč village were used. Two films, showing one very "dry" and one very "wet" flow surge (\# 7 and 9) were selected, and used for calibration purposes. The real cross sections of the artificially aligned Brusnik channel with the Manning roughness coefficient of $0.05 \mathrm{~s} . \mathrm{m}^{-1 / 3}$ and the longitudinal slope of $\mathrm{S}=0.20$ were used as the input geometry data. No samples of debris-flow material were taken in the field, and only laboratory data on fines were used for calibration purposes.

The debris flow surge \# 9 was in the longitudinal direction of a trapezoidal form: the front depth was $1.3 \mathrm{~m}$, the tail was $0.5 \mathrm{~m}$ thick, and it was $35 \mathrm{~m}$ long. For the volume estimation the Brusnik aligned channel cross section dimensions were used, and the total surge volume was estimated at $140 \mathrm{~m}^{3}$. The front average velocity was evaluated as $1.0 \mathrm{~m} / \mathrm{s}$, and the flow rate computed as $5.72 \mathrm{~m}^{3} / \mathrm{s}$. The flow surge advanced steadily, it was wet and a silt fraction was present mainly in the tail. High friction between rock particles with low viscosity was the result.

The debris flow surge \# 7 was in the longitudinal direction of a triangular form: the front depth was $2.5 \mathrm{~m}$, it had no tail 
and it was $12 \mathrm{~m}$ long. Done in the same way as for debris flow surge \# 9, the total volume for debris flow surge \# 7 was estimated at $128 \mathrm{~m}^{3}$. The front velocity stayed below $0.7 \mathrm{~m} / \mathrm{s}$, with an average value of $0.35 \mathrm{~m} / \mathrm{s}$. The debris flow surge was dry, the front occasionally stopped and was pushed further by the inflowing wet mixture; after such a push the behavior and the geometry were quite similar to debris flow surge \# 9, but more viscous.

The observed depth and flow velocity values were used for model calibration. The viscosity, $\eta$, and the yield stress, $\tau$, are material properties that can generally be determined by laboratory analyses directly from samples of debris flows. However, our experiences from the case of the Stože debris flow (Četina et al., 2006) have shown that these analyses cannot be reliably done for a complex mixture with different grain sizes up to $1 \mathrm{~m}$. In the case of the Strug landslide, no debris-flow material samples were taken in the field. Therefore, we decided to assess these two parameters by model calibration. The comparison between the observed and the simulated flow depth by DEBRIF-1D, for the debris flow surge \# 9, is shown in Fig. 4.

To obtain the average flow velocity of $1.0 \mathrm{~m} / \mathrm{s}$ for the debris flow surge \# 9, the input rheological parameters used in DEBRIF-1D were $\tau=20 \mathrm{~N} / \mathrm{m}^{2}$ and $\eta=20$ Pa.s, and $K=1000$. The bulk density of the mixture was calculated as $16.9 \mathrm{kN} / \mathrm{m}^{3}$, using an estimated $\mathrm{C}_{v}=0.40$ and the measured sediment density of $27.14 \mathrm{kN} / \mathrm{m}^{3}$. These values are comparable to those obtained by back analysis for one of the simulated debris flows (Case B) for the village of Log pod Mangartom: $\tau=20 \mathrm{~N} / \mathrm{m}^{2}$ and $\eta=10$ Pa.s (Četina et al., 2006).

Using the dimensionless Chezy coefficient:

$C_{c}^{*}=\frac{v}{\sqrt{g h S}}$,

where $\mathrm{S}$ represents the channel slope $\left(\mathrm{m} \mathrm{m}^{-1}\right), \mathrm{h}$ is the surge depth $(\mathrm{m})$, and $\mathrm{g}$ the acceleration due to the gravity, one can estimate flow resistance. For the debris flow surge \# 9 the flow resistance is estimated by $C_{c}^{*}=v / \sqrt{g h S}=1.0 / \sqrt{9.811 .30 .20}=0.63$. The value is smaller than the interval $C_{c}^{*}=1.0-3.0$, where most of the observed data fit according to Gregoretti (2000) and Rickenmann and Weber (2000). The reason for that is the relatively high volume concentration value $\mathrm{C}_{v}=0.40$.

To obtain the average flow velocity of $0.35 \mathrm{~m} / \mathrm{s}$ for the debris flow surge \# 7, the input rheological parameters used in DEBRIF-1D were $\tau=2000 \mathrm{~N} / \mathrm{m}^{2}, \eta=180$ Pa.s, and $K=1000$. The bulk density of the mixture was estimated as $18.6 \mathrm{kN} / \mathrm{m}^{3}$, using $\mathrm{C}_{v}=0.50$ and sediment density of $27.14 \mathrm{kN} / \mathrm{m}^{3}$. This was comparable to the results obtained for one of the simulated debris flows (Case A) for the village of Log pod Mangartom: $\tau=2000 \mathrm{~N} / \mathrm{m}^{2}$ and $\eta=156$ Pa.s (C̆etina et al., 2006). For the debris flow surge \# 7 the flow resistance is estimated by $C_{c}^{*}=v / \sqrt{g h S}=0.35 / \sqrt{9.812 .50 .20}=0.16$. The value, which is smaller than the value for the debris flow surge \# 9 ,

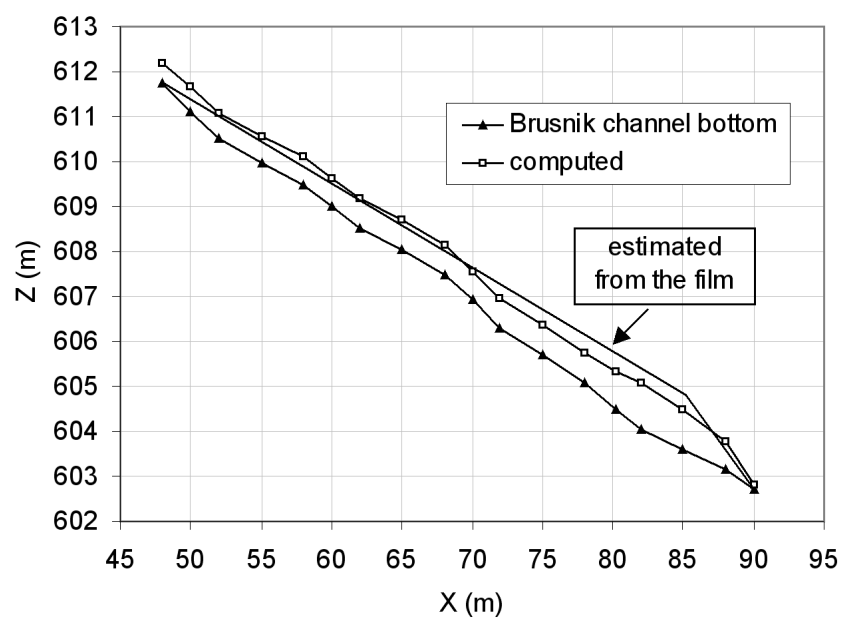

Fig. 4. The calibration of the DEBRIF-1D model - longitudinal profile for the debris flow surge \# 9 with an estimated volume of $132.7 \mathrm{~m}^{3}$, using $\tau=100 \mathrm{~N} / \mathrm{m}^{2}$ and $\eta=22.8$ Pa.s, after the computational time of $28.6 \mathrm{~s}$.

confirms very high flow resistance and explains the unsteady advancing of the surge. The unsteady behaviour of debris flow surge \# 7 forced the usage of the average velocity for calibration purposes. Calibration of the FLO-2D model gave partially but not significantly different values of rheologic parameters to those of the DEBRIF-1D model. For debris flow surge \# 9, the following values were obtained: $\tau=100 \mathrm{~N} / \mathrm{m}^{2}$, $\eta=24$ Pa.s, and $K=1000$. The reason lies in the fact that both models differ in some details, as for example, the 1-D model channel geometry is digitally described with cross sections, while in the 2-D model the topography is described with a given reference bottom level in each control volume of the 2 -D numerical grid. Also, the applied numerical method is different.

The sensitivity analysis has shown that the most important parameters in the FLO-2D model are $K$ and/or $\eta$ Eq. (1). The relevance of the roughness parameter $n_{g}$ is smaller, and the yield stress $\tau$ even smaller. This was not the case when using the FLO-2D model for the Stože debris flow (Četina et al., 2006), where the most important model parameter was the roughness parameter $n_{g}$. The reasons for that are different geometries in both case studies, and different rheological characteristics of both debris flows: in the case of the Strug debris flows, due to small flow depths and relatively coarse granular composition with only a small percentage of clay and silt fractions, inter-granular forces are more important than in the case of the Stože debris flow.

The Manning coefficient of $0.05 \mathrm{~s} . \mathrm{m}^{-1 / 3}$ used in simulations seems to be low, but it should be remembered that the Brusnik channel is practically prismatic and artificially aligned with rip-rap protected banks. Using the FLO-2D model, Bertolo and Wieczorek (2005) used $n_{g}$ values ranging from 0.04 to 0.75 for channels and Bello et al. (2000) used 


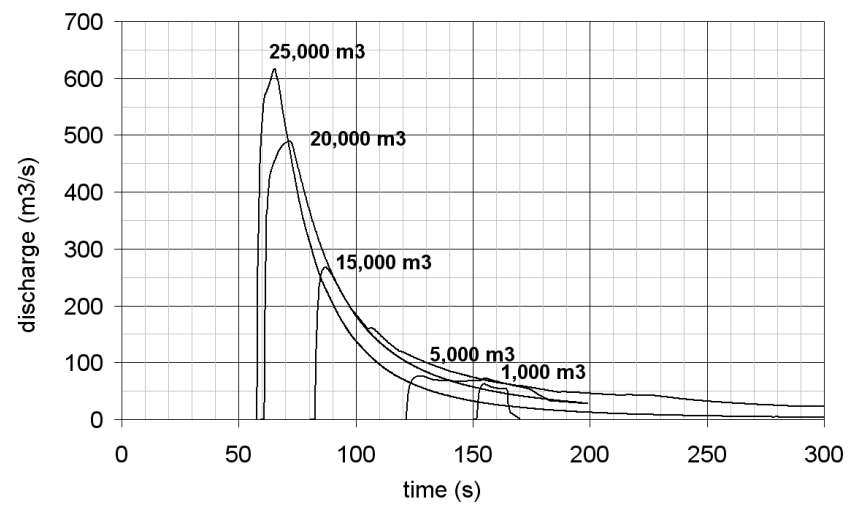

Fig. 5. The hydrographs at the entrance into Koseč village determined for different scenarios in $\mathrm{m}^{3}$ by the DEBRIF-1D model and used as input for the FLO-2D model.

values from 0.032 to 0.062 for channels and 0.05 to 0.06 for floodplains.

Simulations were run with different parameters to assess sensibility of the model (see Fig. 6). Since $K$ and $\eta$ figure as a product in the friction slope equation, we varied only the value of $K$, which was more convenient. A $100 \%$ increased value of $K=2000$ (basically product of $K$ and $\eta$ ) gave $9 \%$ higher depths on average and $25 \%$ lower maximum cross section velocities. A $50 \%$ increased value of $n_{g}=0.075 \mathrm{~s} \mathrm{~m}^{-1 / 3}$ gave $4 \%$ higher depths on average and $13 \%$ lower maximum cross section velocities. Both increased values for $K$ and $n_{g}$ are, according to our knowledge, on the upper limit that is still physically reasonable.

The experiences with calibration of the models and numerical simulations of the Stože debris flow were also used (Četina et al., 2006). Because only debris flows with small volumes $\left(140 \mathrm{~m}^{3}\right.$ and $\left.160 \mathrm{~m}^{3}\right)$ have been taken into account during the model calibration, the final choice of the rheological parameters for numerical simulations with selected scenarios $\left(1000 \mathrm{~m}^{3}\right.$ to $\left.25000 \mathrm{~m}^{3}\right)$ was slightly moderated (Table 2). For the fifth scenario with $20000 \mathrm{~m}^{3}$ of wet mixture lower values for rheological parameters $\tau=10 \mathrm{~Pa}$ and $\eta=5 \mathrm{~Pa}$ s were used, in line with the lower $\mathrm{C}_{v}=0.45$ value. The chosen $\mathrm{C}_{v}$ values were assumed in such a way that the mixture would still behave like a fluid. Using lower $\mathrm{C}_{v}$ values would yield higher peak discharges and smaller flow depth and consequently smaller hazard.

\subsection{Simulation results and discussion}

The numerical simulations with DEBRIF-1D were performed for all selected scenarios in computational reach from the rock fall source area to the end of the regulated Brusnik channel at the downstream end of Koseč. The debris flows were initiated in the Strug rock fall source area and flowed for $800 \mathrm{~m}$ in the natural channel, roughly trapezoidal in form, to enter the regulated part of the Brusnik channel at the channel

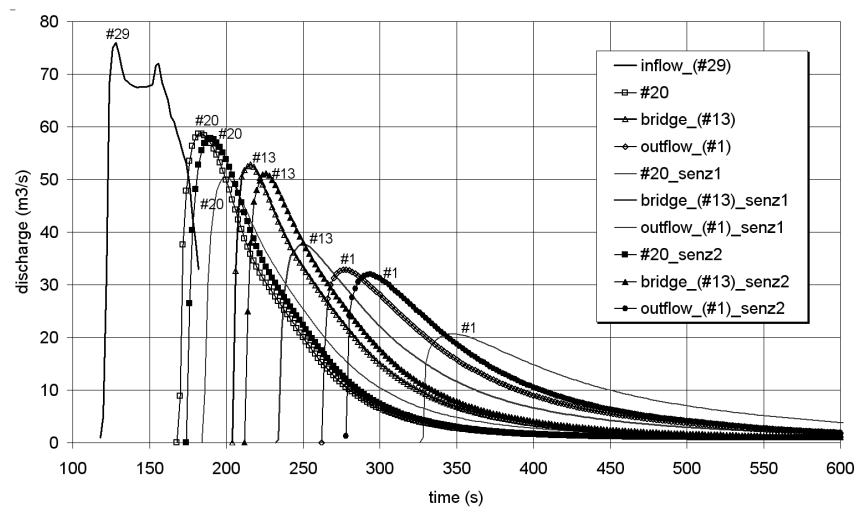

Fig. 6. The computed hydrographs for the scenario with $5000 \mathrm{~m}^{3}$ and for the existing Brusnik channel geometry, using the FLO-2D model. Inflow hydrograph and computed hydrographs are shown for three cross sections (\# 1, 13, and 20) and for the following cases:

1. the calibrated coefficients $\left(n_{g}=0.05 \mathrm{sm}^{-1 / 3}, \quad K=1000\right.$, $\tau=100 \mathrm{~Pa}, \eta=24 \mathrm{~Pa} . \mathrm{s})$,

2. the case "senz1" $\left(n_{g}=0.05 \mathrm{sm}^{-1 / 3}, K=2000, \tau=100 \mathrm{~Pa}\right.$, $\eta=24$ Pa.s) and

3. the case "senz2" $\left(n_{g}=0.075 \mathrm{sm}^{-1 / 3}, K=1000, \tau=100 \mathrm{~Pa}\right.$, $\eta=24$ Pa.s).

elevation of $621.88 \mathrm{~m}$ a.s.l. The simulated debris flow hydrographs at this point, determined for selected scenarios using DEBRIF-1D and used as input for the FLO-2D model are given in Fig. 5.

The numerical simulations with the FLO-2D model were performed for 5 selected scenarios in the 380-m long computational reach between cross sections \# 1 (downstream end) and \# 29 (upstream end). Two different geometries were used: the existing regulated Brusnik channel from 2002 and the new proposed geometry. For the latter only two scenarios with $25000 \mathrm{~m}^{3}$ and with a constant flow rate of $500 \mathrm{~m}^{3} / \mathrm{s}$ were computed. The computational area of 6.5 ha was discretised with a rectangular net of 65239 cells of $1 \times 1 \mathrm{~m}$. As the basis to develop a digital terrain model a 1:2000 topographic map from 2002 was used.

The hydrographs from the 1-D model were used as the upper boundary condition for the 2-D model. The resulting hydrographs in cross sections \# 29,20,13, and 1, respectively, for the scenario with $5000 \mathrm{~m}^{3}$, are shown in Fig. 6. For the existing geometry and for the scenarios with $25000 \mathrm{~m}^{3}$ and the constant flow rate $500 \mathrm{~m}^{3} / \mathrm{s}$, the maximal envelope of the debris flow is shown in Fig. 7.

The example of a wet debris flow with $20000 \mathrm{~m}^{3}$ gives higher maximal discharges. The results showed that due to lower energy losses the maximal flow depths were smaller than those computed for the scenario with $25000 \mathrm{~m}^{3}$ of a dry debris flow, using validated rheological parameters. 
Table 2. Scenarios used and the corresponding model parameters.

\begin{tabular}{lllll}
\hline $\begin{array}{l}\text { Initial } \\
\text { volume } \\
\left(\mathrm{m}^{3}\right)\end{array}$ & $\begin{array}{l}\text { Viscosity } \\
(\text { Pa.s })\end{array}$ & $\begin{array}{l}\text { Yield } \\
\text { stress } \tau \\
\left(\mathrm{N} / \mathrm{m}^{2}\right)\end{array}$ & $\begin{array}{l}\text { Coefficient of } \\
\text { laminar resistance } K \\
(-)\end{array}$ & $\begin{array}{l}\text { Manning } \\
\text { roughness } n_{g} \\
\left(\mathrm{sm}^{-1 / 3}\right)\end{array}$ \\
\hline 1000 & 24 & 100 & 1000 & $0.2 / 0.05^{*}$ \\
5000 & 24 & 100 & 1000 & $0.2 / 0.05$ \\
15000 & 24 & 100 & 1000 & $0.2 / 0.05$ \\
25000 & 24 & 100 & 1000 & $0.2 / 0.05$ \\
20000 & 5 & 10 & 1000 & $0.2 / 0.05$ \\
\hline
\end{tabular}

* The value of 0.2 was used for the entire natural Brusnik channel upstream of the aligned channel, and the value of 0.05 was used for the aligned Brusnik channel through the Koseč village, respectively.

The results of both models were compared to each other. For the scenario using $25000 \mathrm{~m}^{3}$, the simulated hydrographs at the end of the computational reach (see Fig. 8) show fair agreement using both models. The differences are to some extent due to the different mathematical concepts of the models, and much more due to the fact that the FLO-2D model allows overflow of the levees. This can be seen from Fig. 9, where the maximum levels along the computational reach in Kosec are shown for both models for the scenario using $25000 \mathrm{~m}^{3}$. The level simulated with DEBRIF-1D is locally higher than the level simulated with the FLO-2D model. The main reason for differences between the models is overflow. The second reason is that in DEBRIF-1D the surface is horizontal, which is not the case for the FLO-2D model. The overall agreement is fairly good, because the overflow is limited, and thus the differences between the results of both models are moderate. The same conclusion was drawn when modeling the Stože debris flows (Četina et al., 2006).

The 2-D simulation showed that the retention effects of the regulated Brusnik channel are noticeable, as shown in Fig. 6. In a way, this effect is expected because the volumes of simulated debris flows are comparable to the volume of the Brusnik channel in the computational reach $\left(16000 \mathrm{~m}^{3}\right.$ at $4 \mathrm{~m}$ flow depth). As an example, the storage volume of the channel between cross sections \# 13 and \# 29 is $\sim 10000 \mathrm{~m}^{3}$ at a flow depth of $4 \mathrm{~m}$. The other possible explanation for such a flattening of the hydrograph is the fact that the 2D model cannot describe all physical phenomena precisely enough, and therefore this effect in the model is exaggerated. Lacking any field data regarding retention effects, as well as for safety reasons, another simulation with a constant flow rate of $500 \mathrm{~m}^{3} / \mathrm{s}$ was performed, corresponding to the maximum flow rate for the scenario with $25000 \mathrm{~m}^{3}$. In this situation, the 2-D model gave an only slightly larger overflow area than that for the scenario using $25000 \mathrm{~m}^{3}$, and this was considered as a good result. The average flow velocity in the cross sections at the constant flow rate was $\sim 8 \mathrm{~m} / \mathrm{s}$. The maximum was reached at $12-14 \mathrm{~m} / \mathrm{s}$ in the middle part of the cross section, whereas the flow velocities at low depths were much smaller, $\sim 1-2 \mathrm{~m} / \mathrm{s}$. These values are naturally much higher than in the calibration cases with much lower total volumes of $140 \mathrm{~m}^{3}$ and $128 \mathrm{~m}^{3}$, respectively.

The 2-D model accuracy was assessed using two additional sensitivity runs: one with increased $K=2000$ (run "senz 1 " in Fig. 6), and one with increased $n_{g}=0.075$ (run "senz 2" in Fig. 6). The retention effect of the Brusnik channel can be clearly seen, as hydrographs are given for selected cross sections. It is clearly more pronounced for the case "senzl", illustrating the higher effect of $K$ on flow depths and celerity. The 2-D model precision for the scenario using $25000 \mathrm{~m}^{3}$ was therefore assessed at $\pm 30 \mathrm{~cm}$, on average, in the longitudinal direction. The precision of the model increases in the lower part of the computational reach due to flow retention effects. This estimation does not take into account the computational error when simulating the hydrograph translation from the Strug rock fall source area to the upstream end of the computational reach using the 1-D model. Using the results of the 2-D model for the constant flow rate of $500 \mathrm{~m}^{3} / \mathrm{s}$ this error can be eliminated to a large extent and the retention effects in the model may decrease.

The new proposed geometry was developed using the results of the numerical simulations for the existing geometry. The proposed changes to the regulated Brusnik channel are:

- the longitudinal defence wall between cross sections \# 13 and \# 20 is a safety margin for the scenario using $25000 \mathrm{~m}^{3}$ and is needed for the case with the constant flow rate of $500 \mathrm{~m}^{3} / \mathrm{s}$ to physically avoid spilling over the existing levee;

- deepening of the channel between cross sections \# 6 and \# 17 with a new concrete bridge had very positive effect on decreasing debris flow levels when compared to the existing channel geometry. The levels would be lower, on average, by $1.3 \mathrm{~m}$, and maximally by $2 \mathrm{~m}$ around the bridge for the scenario using $25000 \mathrm{~m}^{3}$ and for the case with the constant flow rate of $500 \mathrm{~m}^{3} / \mathrm{s}$; 

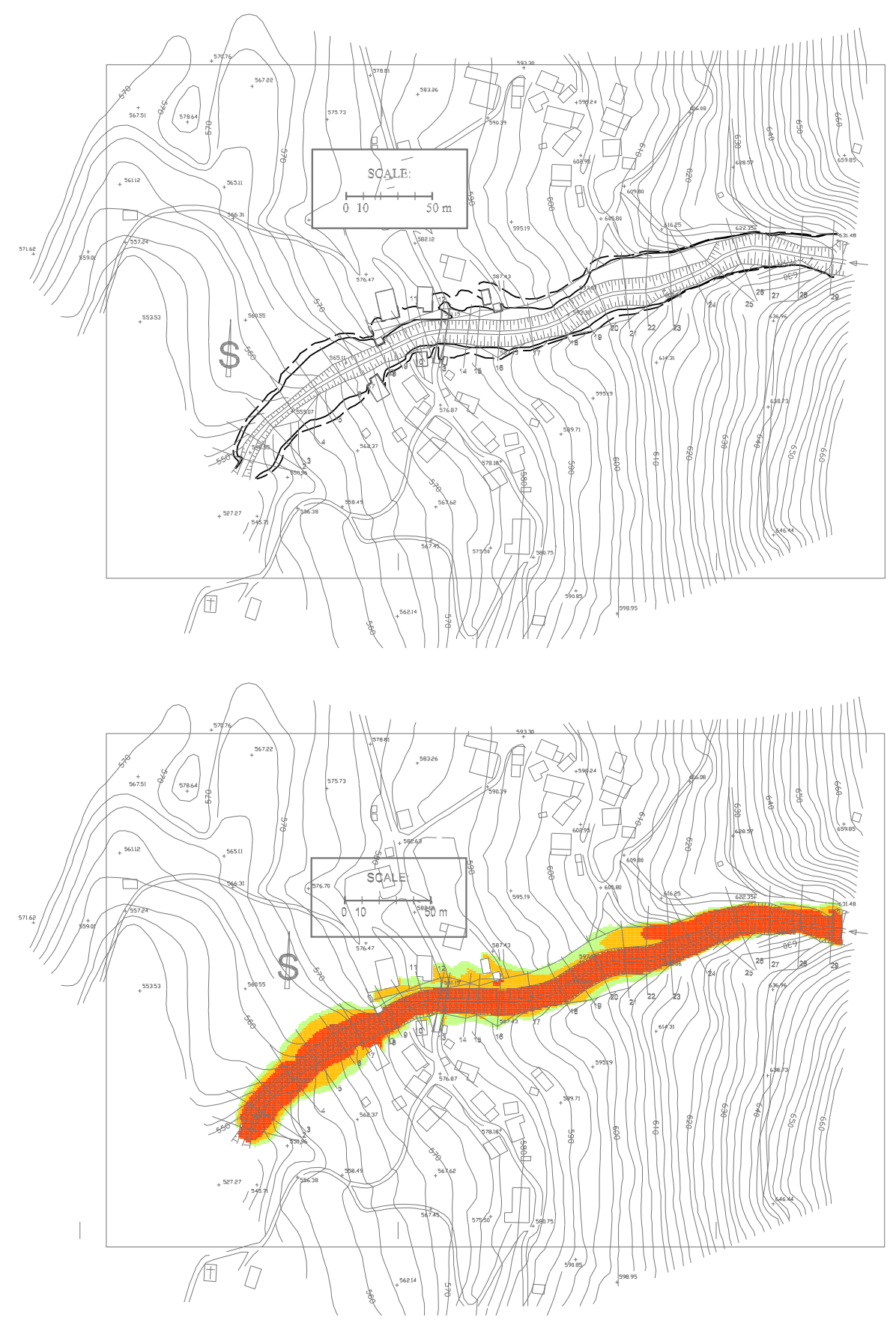

Fig. 7. The hazard map of the Koseč village prepared with the two-dimensional FLO-2D model using the existing Brusnik aligned channel geometry (present situation). In all cases a dry debris flow is assumed, because a wet debris flow gives higher peak discharges, but due to lower energy losses the computed maximum flow depths are lower and also the inundated area is smaller than in a comparable dry event. The upper map shows delineation of the inundated area along the Brusnik Stream for the scenario with $25000 \mathrm{~m}^{3}$ (full line) and for the case with a constant flow rate $500 \mathrm{~m}^{3} / \mathrm{s}$ (dashed line). The lower map shows the product of flow depth and flow velocity in three zones $\left(<1 \mathrm{~m}^{2} / \mathrm{s}\right.$, $1-4 \mathrm{~m}^{2} / \mathrm{s},>4 \mathrm{~m}^{2} / \mathrm{s}$ ), for the case with a constant flow rate $500 \mathrm{~m}^{3} / \mathrm{s}$.

- a low sill in cross section \# 3 with a small levee as a deflector to convey smaller debris flows to a retention area on the right side of the channel. The low sill would have only small effects on changing the hydrograph in the downstream direction, as well as on raising the levels in the upstream direction. The discharge into the downstream reach would be smaller by $\sim 15 \mathrm{~m}^{3} / \mathrm{s}$ or the hydrograph volume would decrease by $\sim 650 \mathrm{~m}^{3}$. The 


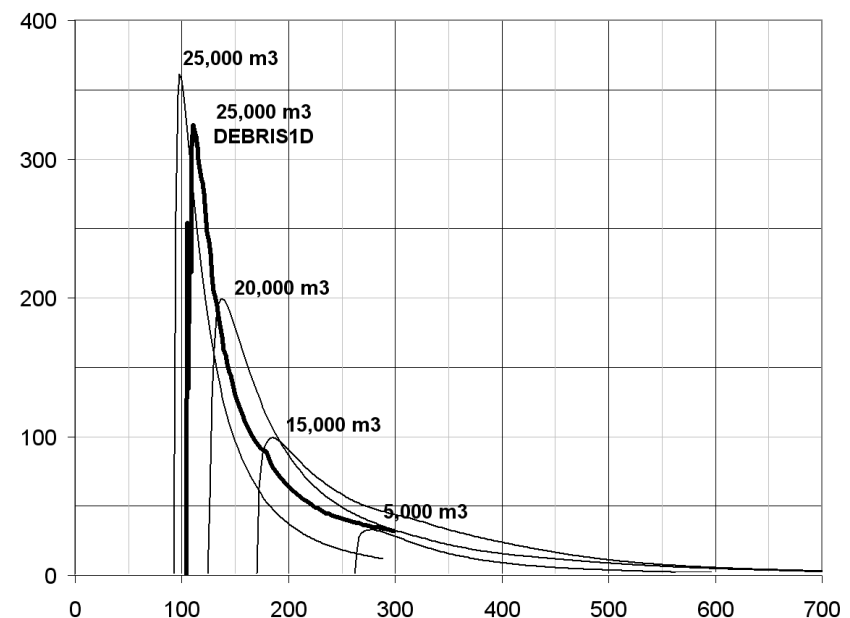

Fig. 8. The hydrographs at the end of the computational reach through the Koseč village determined for different scenarios in $\mathrm{m}^{3}$ using the FLO-2D model. For the scenario with $25000 \mathrm{~m}^{3}$ the resulting hydrograph using the DEBRIF-1D model is also added for comparison.

effect of the sill would be increased by lowering the right channel bank and thus directing the debris flow to enter the retention area easily. The effect would be anyway limited by the sharp form of the hydrographs and relatively high longitudinal flow velocities of debris flows.

For the scenario using $25000 \mathrm{~m}^{3}$ and also for the constant flow rate of $500 \mathrm{~m}^{3} / \mathrm{s}$ only a few structures in Koseč are endangered (Fig. 7). All other structures in Koseč are safe regarding the debris flow hazard from the Strug rock fall source area.

In 2002, the regulation of the Brusnik natural channel was performed to enlarge the channel and to raise the levees. These works have greatly increased the debris flow safety of the village, because the existing channel nowadays can convey debris flows with a total volume up to $15000 \mathrm{~m}^{3}$, which is up to several times 10 more than the estimated volumes of the observed debris flows in 2002.

\section{Conclusions}

The mathematical modelling of debris flows triggered in the Strug rock fall source area, using field data from registered debris flows in 2002, was used to establish a hazard map of the Kosec village below the Strug landslide. The main conclusions which can be drawn from this study are as follows:

1. The calibration of a one-dimensional mathematical model DEBRIF-1D for simulations of debris flows was successfully done using short film sequences of real debris flow surges with volumes up to $160 \mathrm{~m}^{3}$. For final

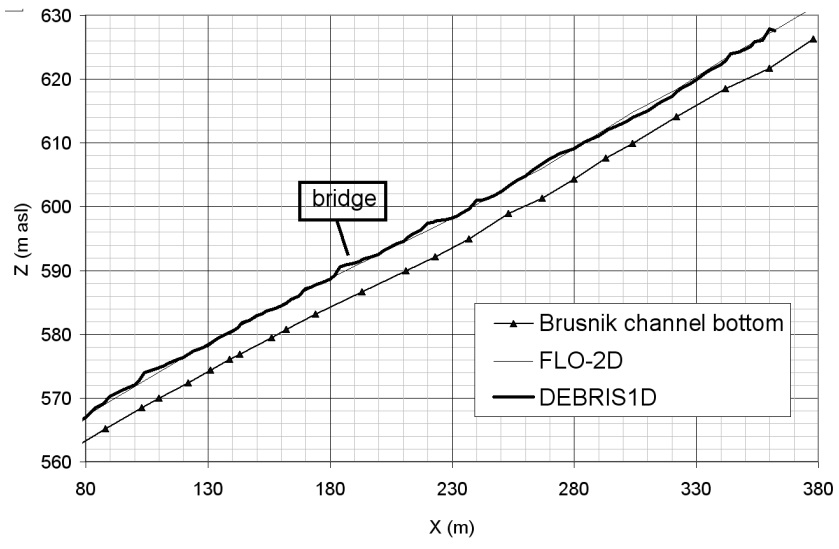

Fig. 9. The maximum levels of the debris flow in the computational reach through the Koseč village for the scenario with $25000 \mathrm{~m}^{3}$, using the DEBRIF-1D model and the FLO-2D model, respectively.

calibration and for simulating future events the gained experiences when modeling other debris flows were taken into account as well.

2. The precision of both mathematical models used for numerical simulations of future debris flows (DEBRIF$1 \mathrm{D}$, FLO-2D) may be estimated at $\pm 10 \%$ with regard to flow depth. This possible model inaccuracy is smaller than the uncertainty about the estimated volumes of debris flows used as selected scenarios by assuming $\mathrm{C}_{v}$ values for mixtures to still behave like a liquid.

3. Numerical simulations of debris flows from the Strug rock fall source area were successfully performed using two different mathematical models. The results obtained by the FLO-2D model were practically used in preparation of a hazard and risk map of the area below the Strug landslide.

4. Both mathematical models have proved that the regulated Brusnik channel can convey the debris flows with a volume up to $15000 \mathrm{~m}^{3}$. The most extreme debris flow event used in the study was estimated at $25000 \mathrm{~m}^{3}$. Such a debris flow would partially (locally) overtop the existing levees along the regulated Brusnik channel as simulated by the FLO-2D model. For this reason, additional river engineering measures have been proposed, such as raising of the levees and construction of a righthand side sedimentation area for debris flows at the downstream end of the regulated reach.

Acknowledgements. This research is funded by the State Rehabilitation Commission of the Republic of Slovenia and by the Ministry of Higher Education, Science and Technology of the Republic of Slovenia, research programme No. P2-180-0792 "Hydrotechnics, Hydraulics, and Geotechnics". The comments of L. Marchi and other two reviewers helped to improve the draft version of the 
paper. The authors would like to thank M. Vilfan who helped with text editing and A. McConnell-Duff who proofread the text.

Edited by: F. Guzzetti

Reviewed by: L. Marchi and two other referees

\section{References}

Aleotti, P. and Polloni, G.: Two-dimensional model of the 1998 Sarno debris flows (Italy): preliminary results, Debris-Flows Hazard Mitigation: Mechanics, Prediction, and Assessment, edited by: Rickenmann, D. and Chen, C.-L., Millpress, Rotterdam, 553-563, 2003.

Bello, M. E., O’Brien, J. S., Garcia-Martinez, R., and Lopez, J. L.: Simulation of Flooding and Debris Flows in the Cerro Grande River, Seminario International "Los Alludes Torrencialles de Diciembre 1999 en Venezuela", Instituto de Mecanica de Fluidos, Caracas, Venezuela, 2000.

Bello, M. E, O’Brien, J. S., Lopez, J. L., and Garcia-Martinez, R.: Simulation of flooding and debris flows in the Cerro Grande river, Libro de resúmenes Jornadas de Investigación Facultad de Ingeniería, JIFI 2000, Universidad Central de Venezuela, 531, 2000.

Bertolo, P. and Wieczorek, G. F.: Calibration of numerical models for small debris flows in Yosemite Valley, California, USA, Nat. Hazards Earth Syst. Sci., 5, 993-1001, 2005.

Brufau, P., Garcia-Navarro, P., Ghilardi, P, Natale, L., and Savi, F.: 1-D Mathematical modelling of debris flow, J. Hydraulic Res., 38, 6, 435-446, 2000.

Canuti, P., Casagli, N., Catani, F., and Falorni, G.: Modeling of the Guagua Pichincha volcano (Ecuador) lahars, Phys. Chem. Earth, 27, 1587-1599, 2002.

Četina, M., Rajar, R., Hojnik, T., Zakrajšek, M., Krzyk, M., and Mikoš, M.: Case Study: Numerical Simulations of Debris Flow Below Stože, Slovenia, J. Hydraulic Eng., 132, 121-130, 2006.

Elliott, J. G., Smith, M. E., Friedel, M. J., Stevens, M. R., Bossong, C. R., Litke, D. W., Parker, R. S., Costello, C., Wagner, J., Char, S. J., Bauer, M. A., and Wilds, S. R.: Analysis and mapping of post-fire hydrologic hazards for the 2002 Hayman, Coal Seam, and Missionary Ridge wildfires, Colorado, U.S. Geolog. Survey Sci. Invest. Rep. 2004-5300, 104, 2005.

FLO Eng.: FLO-2D, User's manual, Version 99.1, Flo Eng. Inc., 1999.

Gregoretti, C.: Estimation of the maximum velocity of a surge of debris flow propagation along an open channel, Proc. Int. Symposion INTERPRAEVENT, Villach, Austria, 3, 99-108, 2000.

Hübl, J. and Steinwendtner, H.: Two-dimensional simulation of two viscous debris flows in Austria, Phys. Chem. Earth, Part C, 26, 9, 639-644, 2001.
Jin, M. and Fread, D. L.: One-dimensional routing of mud/debris flows using NWS FLDWAV model, Debris-Flows Hazard Mitigation: Mechanics, Prediction, and Assessment, edited by: Chen, C.-L., ASCE Press, New York, 687-696, 1997.

Legros, F.: The mobility of long-runout landslides, Eng. Geolog., 63, 301-331, 2001.

Lin, M.-L., Wang, K.-L., and Huang, J.-J.: Debris flow run off simulation and verification - case study of Chen-You-Lan watershed, Taiwan, Nat. Hazards Earth Syst. Sci., 5, 439-445, 2005.

Lorente, A., Beguería, S., Bathurst, J. C., and García-Ruiz, J. M.: Debris flow characteristics and relationships in the Central Spanish Pyrenees, Nat. Hazards Earth Syst. Sci., 3, 683-692, 2003.

Majes, B., Petkovšek, A., and Logar, J.: The comparison of material properties of debris flows from Stože, Slano blato and Strug landslides (in Slovenian), Geologija, 45, 457-463, 2002.

Marchi, L. and D'Agostino, V.: Estimation of debris-flow magnitude in the Eastern Italian Alps, Earth Surface Processes and Landforms, 29, 207-220, 2004.

Mikoš, M., Vidmar, A., and Brilly, M.: Using a laser scanner measurement system for monitoring morphological changes on the Strug rock fall, Slovenia, Nat. Hazards Earth Syst. Sci., 5, 143 $153,2005$.

Mikoš, M., Brilly, M., Fazarinc, R., and Ribièiè, M.: Strug landslide in W Slovenia: a complex multi-process phenomenon, Eng. Geology, 83, 22-35, 2006.

O'Brien, J. S.: Reasonable assumptions in routing a dam break mudflow, Debris-Flows Hazard Mitigation: Mechanics, Prediction, and Assessment, edited by: Rickenmann, D. and Chen, C.L., Millpress, Rotterdam, 683-693, 2003.

O'Brien, J. S., Julien, P. Y., and Fullerton, W. T.: Two-Dimensional Water Flood and Mudflow Simulation, J. Hydraulic Eng., 119(2), 244-261, 1993.

Rajar, R.: Mathematical Simulation of Dam-Break Flow, J. Hydraulic Eng., 104(7), 1011-1026, 1978.

Rajar, R.: Mathematical models for simulation of flood waves, dambreak waves and snow avalanches, Proc. Int. Symposion INTERPRAEVENT, Bad Ischl, Austria, 232-234, 1980

Rickenmann, D.: The empirical relations for debris flows, Nat. Hazards, 19, 47-77, 1999.

Rickenmann, D. and Weber, D.: Flow resistance of natural and experimental debris-flows in torrent channels, Debris-Flows Hazard Mitigation: Mechanics, Prediction, and Assessment, edited by: Wieczorek, G. F. and Naeser, N. D., Balkema, Rotterdam, 245-254, 2000.

VGB: Two-dimensional mathematical model for debris flows in the area of Koseč with the debris flow risk assessment for Koseč, Unpublished Report No. 2644/04, Vodnogospodarski Biro Maribor, Maribor, 2004 